\title{
IFNAR1 Gene
}

National Cancer Institute

\section{Source}

National Cancer Institute. IFNAR1 Gene. NCI Thesaurus. Code C37275.

This gene is involved in tyrosine-kinase signal transduction and receptor mediation. 